\title{
AN EVALUATION OF WH-QUESTION IN ENGLISH IN MIND TEXTBOOK AN BRIGHT AN ENGLISH TEXTBOOK SEEN IN TERMS OF BLOOM'S NEW TAXONOMY
}

\author{
Intan Kristen G. Takasana
}

\begin{abstract}
The study aimed at identifying and analyzing the types and levels of WH-question in two English Textbooks namely, English in Mind Textbook (EIM) and Bright An English Textbook (BAE) for eighth grade junior high school. The objective of the analysis was to evaluate the WH -questions in the light of the Bloom's New Taxonomy (1956) Taxonomy learning objectives ( Remembering, Understanding, Applying, Analyzing, Evaluating, Creating).Content analysis was used to conducted all the WH-questions in the two textbooks. All the WH-questions were collected, listed, and analyzed according to Bloom's New Taxonomy. The result from a total of 140 questions (70 questions in EIM and 70 questions in BAE) showed that most of the questions were align with remembering, understanding, and applying as the three lower - level categories, while analyzing, evaluating, and creating as the three higher-level categories constitude the lowest frequency in the two textbooks.Another result also for the proportion of higher-order questions in both Textbook showed that EIM received higher distribution while BAE constitute the highest distribution on lower-order questions. The result indicate that the textbooks failed to engage learners in the questions requiring higher levels of cognitive learning objectives.In the light of the results, the researcher suggested to modified the questions in the textbooks to cover the six levels of Bloom's new Taxonomy and to train teachers and author of textbook to use and write question following the Bloom's new Taxonomy.
\end{abstract}

Keywords : Bloom's New Taxonomy, WH-questions, content analysis, English Textbook

\section{INTRODUCTION}

Questions are one of the important aspects in developing thinking skills. Thinking activity begins with the questions. As Aslan (2011) stated that " Questions are parts of a textbook that openly interact with the students, and are directly posed to students". Its stimulates the students to a deeper thinking process and develop their analytical, creative thinking and problem solving abilities and As an important element of textbook it also depends on how good the textbook is. In English language teaching especially textbook become an important instrument in teaching. It is serve as a quide for teachers and students of any level of education to be actively engaged in classroom practices. But the question is : Do question in textbook help in engaging the students in developing their higher order thinking skill ? some findings have shown that questions in textbooks promote only lowerorder thinking skills. As Ayaturochim (2014) who investigate the dominant of Cognitive Domain of Revised Bloom's Taxonomy in Reading Task of "English in Focus" textbook, found that there are only 2 component of cognitive domain were used while the other levels are not exist and Remembering level was the dominant component in the textbook. Moreover, Katemba and Marrie (2016) who analyzed teacher's questioning and student critical thinking in classroom, revealed that most of the questions were dominated of lower cognitive questions and had small number in higher cognitive questions.

JELLT (Journal of English Language and Literature Teaching)

Vol. 5 No. 02 November 2020

P.ISSN: 2548-7728 E.ISSN: 2599-0373 
Consider, the significance of higher order question in textbook, it is really important to evaluate the question and examine its contribution to the educational system in general and to the area of students' higher order thinking in particular. in order to help the students to achieve the higher order thinking process it would not be succeed without teachers role as a facilitator. Indonesian 2013 curriculum demanded that teachers should be a facilitator in the classroom for students. As Liando (2010) stated that "Students and teachers were two impact figures in the teaching and learning process. In this situation such in Indonesia, less student-centered but more teacher-centered was the common approach applied in the classroom all across subject areas". As Maru (2009) also argued that " Teachers solely employ a textbook as a learning source and rarely express themselves in English even for simple converse during the teaching session as well as act as the only one knows the text material used in the class position students as passive objects who have no opportunity to express their ideas, response and thought flourish the teaching and learning of English". In addition Liando (2010) also stated that "Despite the efforts of promoting students centered approach, the practice was clearly showing that teacher still held more dominant role as far as teaching English was concerned". That is why teachers have a role to create opportunity for students to be active in learning process and learn in a more responsible and challenging manner but most importantly teachers must teach their student how to think and how to use higher order thinking skill. But it can not be denied that when the researcher doing her teaching practice the researcher has observed and learned that most the teachers have tied demanded schedule and very limited time to make their own materials. Those problem made them really depends on the textbooks. That is why it is important to evaluate the textbooks in order to see how it really helps the teachers.
Taxonomy Bloom's is one of the instrument that can be use to evaluate the questions in textbook. As Musial claims that " This Taxonomy has been extremely influential in education fo the past 50 years" (as cited in Nana Pratiwi, 2015). Hence, Bloom's Taxonomy is still considered as a helpful teaching tool today. However in this study, the writer employs Revised edition of Bloom's Taxonomy by Krathwohl and Anderson. This revised edition is an updated version of original Bloom's Taxonomy. In this research English in Mind Textbook and Bright an English was chosen to be object of the research. Therefore, this has led the researcher decide to evaluate the WH-Question in English in Mind Textbook and Bright an English Textbook for eight grade junior high school students based on Bloom's New Taxonomy to make sure that the textbook has been support the students in developing their thinking level by providing higher cognitive question.

\section{RESEARCH METHODOLOGY}

\section{Research Method}

In this research, the writer used the content analysis method because the writer analyzed the contents of the textbook. As Ary (2010) states that "content or document analysis is a research method applied to writteb or visual materials for the purpose of identifying specified characterisation of the material". the writer also employs statistical calculation to determine the frequency of each level of cognitive domain based on Revised Bloom's Taxonomy.

\section{Research Instrument and Data Collection}

The researcher prepared a guide for the levels of questions based on the cognitive domain in Revised Bloom's Taxonomy. This guide included a description of the level of each question together with it's criteria. Moreover, for the purpose of the research, a simple a table 
with four columns has been used to record the data. The first column contained the serial number of the questions, the second contained the question and the third and fourth column wer used for recording the level of the question and the page number in the book which the question appeared.

\section{Data Analysis}

After the data collected the researcher was aided by two English Education Department of UNIMA Lecturers who are considered expert in language testing to help the researcher to do the categorization. Finally, the data then been analyzed quantitavely to determine the frequency and percentage of each category and the proportions of LOQs and HOQs. The analysis been using this formula :

$(\%)$ kemunculan $=$

$\frac{\sum \text { kemunculan aspek tertentu di dalam buku }}{\sum \text { seleuruh soal di dalam buku }} \times 100$

\section{Validity and Reliability of the Research}

\section{Instrument}

Despite the fact that all the researcher know about the validity of Bloom's Taxonomy, the researher gave it to a jury of 2 lecturers from English Education Department. The jury confirmed that the instrument was suitable to achieve the purpose of the study and answer its questions. Furthermore, in order to establish realiability for the analysis, the researcher computed the agreement coefficient between the findings of the two analysis using Holsti's (1969) equation to calculate the reliability coeffiecient. According to the percentage of agreement between the first and second analyst, the agreement coefficient was $83.58 \%$ which is accepted. The reliability was therefore high in relation to categorization of the question within the cognitive domain according to Bloom's Taxonomy. This also shows that the research tool that being used was reliable.

\section{FINDINGS AND DISCUSSION}

\section{Findings}

Table 1. Frequencies And Percentages Of WH-Questions In The Six Levels Of The Cognitive Domain In Bloom's Taxonomy In English In Mind Textbook

\begin{tabular}{|l|c|c|}
\hline \multirow{2}{*}{$\begin{array}{c}\text { Cognitive } \\
\text { Domain }\end{array}$} & $\begin{array}{c}\text { English In Mind } \\
\text { e }\end{array}$ & $\begin{array}{c}\text { Percentag } \\
\text { e }\end{array}$ \\
\hline Lower-Level \\
\hline Remembering & 51 & $72.86 \%$ \\
\hline $\begin{array}{l}\text { Understandin } \\
\text { g }\end{array}$ & 11 & $15.72 \%$ \\
\hline Applying & - & - \\
\hline Higher-Level & \multicolumn{2}{|l|}{} \\
\hline Analyzing & 5 & $7.14 \%$ \\
\hline Evaluating & 2 & $2.85 \%$ \\
\hline Creating & 1 & $1,42 \%$ \\
\hline Total & $\mathbf{7 0}$ & $\mathbf{1 0 0}$ \\
\hline
\end{tabular}

Table 2. Frequencies And Percentage Of

WH- Questions In The Six Levels Of The

Cognitive Domain In Bloom's New

Taxonomy In Bright An English

\begin{tabular}{|c|c|c|}
\hline \multirow{2}{*}{$\begin{array}{c}\text { Cognitive } \\
\text { Domain }\end{array}$} & \multicolumn{2}{|c|}{ Bright An English } \\
\hline & $\begin{array}{c}\text { Frequenc } \\
\text { e }\end{array}$ & $\begin{array}{c}\text { Percentag } \\
\text { e }\end{array}$ \\
\hline \multicolumn{3}{|l|}{ Lower-Level } \\
\hline Remembering & 38 & $54.28 \%$ \\
\hline $\begin{array}{l}\text { Understandin } \\
\mathrm{g}\end{array}$ & 22 & $31.43 \%$ \\
\hline Applying & 2 & $2.86 \%$ \\
\hline \multicolumn{3}{|l|}{ Higher-Level } \\
\hline Analyzing & 3 & $4.29 \%$ \\
\hline Evaluating & 4 & $5.72 \%$ \\
\hline Creating & 1 & $1,42 \%$ \\
\hline Total & 70 & 100 \\
\hline
\end{tabular}

Table 3. Proportion Of Low-Order And

High-Order Question Question In English 
In Mind Textbook And Bright An English

Textbook.

\begin{tabular}{|c|c|c|c|}
\hline \multirow[t]{2}{*}{ Level } & \multicolumn{2}{|l|}{ EIM } & $\begin{array}{l}\text { BAE found higher than Bright an English even } \\
\text { BAmgh its seems should Total bethe highest since its }\end{array}$ \\
\hline & Frequency & Percentage & Frequengkeen Peqrisentageordiforequencicent Carcentage \\
\hline $\begin{array}{l}\text { Low- } \\
\text { order } \\
\text { Question }\end{array}$ & 60 & $85.72 \%$ & $\begin{array}{l}\text { which supposed to support the HOTS. while } \\
62 \text { Bright an English textbook become the highest }\end{array}$ \\
\hline $\begin{array}{l}\text { Higher- } \\
\text { order } \\
\text { Question }\end{array}$ & 10 & $14.28 \%$ & $\begin{array}{l}\text { proportions for the lower-ordet questions. } \\
8 \text { Despite } 1 \text { all } 42 \% \text { that , conpigder how impersgnt } \\
\text { High-order thinking processes the result }\end{array}$ \\
\hline Total & 70 & 100 & $\begin{array}{l}70 \begin{array}{l}\text { indicare that the two pooks are failed to } \\
\text { fasilitate high-order questions in order to }\end{array} \\
\text { in on }\end{array}$ \\
\hline
\end{tabular}
develop students thinking process

\section{Discussion}

The result showed that higher-order question obtains lower distribution that the lower ones in two aforementioned textbooks. This proved by remembering level that was appeared as the most frequently among the six levels with $72.86 \%$. Followed by understanding level processes that come as the second with $15.72 \%$ while the applying was found no exist in the English in Mind textbook. This finding is in agreement with the findings of the previous studies conducted by Ayaturochim (2014) and Katemba and Marrie (2016) who also found that the lower-order cognitive processes dominates the higher ones. It appeared that the author of the textbook was emphasized more on lower-order thinking processes and vocabulary and grammar. The same result also found in Bright an English textbook that show the dominations of Remembering and Understanding level processes $54.28 \%$ and $31.43 \%$ respectively.

The dominations of lower-order processes in the two textbooks is likely to be Bloom's concern to the importance of knowledge and remembering. As Krathwohl (2002) argues that knowledge is frequently trated as a backbone to all the other educations objectives. Moreover, Marzano and kendall (2007) stated that higher-order processes such as evaluating and creating must be based upon the previous knowledge of our realities, which is what we remember. On the other hand, proportions for English in Mind Textbook was

\section{CONCLUSION}

This study come to the conlcusion that the most prevalent level processes in two textbooks were lower-order, that is remembering, understanding, and applying. In other words, the majority of the questions were the three lower level cognitive domains and only a few questions were found to address higher cognitive processes among the six levels of Bloom's New Taxonomy.

It is proven by the result of the data which showed the distribution of the higherorder question and lower-order question in EIM Textbook obtains remembering, understanding (72.86 \%,15.72\%) and analyzing, evaluating and creating $(7.14 \%, 2.85 \%, 1.42 \%)$. While in BAE, Remembering, Understanding, applying $(54,28 \%, 31.43 \%, 2.86 \%)$ and analyzing, evaluating, creating $(4.29 \%, 5.72 \%$, $1.42 \%)$. On the other hand, for the Higherorder questions EIM have higher proportioning than in BAE that is $10(14.28 \%)$ and $8(11.42$ $\%)$. Furthermore, for lower-order questions BAE Textbook have $62(88.28 \%)$ which is the highest score while EIM textbook have 60 $(85.72 \%)$. Therefore, it can be concluded that, based on the results of this research, the main objectives of the two textbooks were the development of lower-order cognitive processes and both of the textbooks were fail in engaging the students to develop their higher thinking skill. 


\section{BIBLIOGRAPHY}

Arikunto, Suharsimi. 2013. Prosedur Penelitian Suatu Pendekatan Praktik. Jakarta: Rineka Cipta.

Ayaturochim. (2014). The Analysis of Reading Tasks in "English in Focus" Textbook Based on Cognitive Domain of Revised Bloom's Taxonomy. A Skripsi. English Language Education Study Program, Department of language and Arts, Faculty of Teacher and Training and Education, Universitas Bengkulu.

Canan Aslan. 2011. High Level Thinking Education in Mother Tounge Textbooks in Turkey and France. The Journal of International Social Research.Vol 4.

Holsti, O.R (1969). Content Analysis for The Social Sciences and Humanities. USA : Addison Wesley Publishing Company

Katemba, Caroline V \& Marie, Aprilia Rose. 2016. Analysis of Teacher's questioning andStudents' Critical Thinking in English Classroom.Retrievedfromfile:///D:/D rive $\% 20$ D/FARNI\%20NGABITO $\%$ 20SKRIPSI/Documents/Downloads/ 277-697-1-SM\%20(2).pdf

Krathwohl, D. (2002). A Revision of Bloom's Taxonomy : An overview. Theory into Practice.

Kunjang, Suropati Sei. 2015. An Analysis of Thinking Order of Reading Coprehension Quesions in English
Textbook for Young Foresters of

Forestry Vocational School of Samarinda. Jurnal Nalar Pendidikan ISSN: 2339-0794 Volume 3 Nomor 1 Hal. 314

Liando, Nitha. 2010. Students' VS Teachers Perspectives on Best Teacher Characteristics in EFL Classrooms. Lembaga Penelitian Unima : Universitas Negeri Manado.2010. Students' VS Teachers Perspectives on Best Teacher Characteristics in EFL Classrooms. Lembaga Penelitian Unima :Universitas Negeri Manado

Pratiwi, Nana. 2014. Analysis of English Workbook for SMP/MTs by Using Revised Bloom Taxonomy. A skripsi. Pendidikan Bahasa Inggris, Fakultas Tarbiya danKeguruan, Unversitas Islam Negeri Syarif Hidayatullah,Jakartahttp://repository.u injkt.ac.id/dspace/bitstream/12345678 9/30 059/1/NANA\%20PRATIWIFITK.pdf

Maru Mister Gidion.2009. Engaging Literary Text to Language Exposure for Foreign English Learners. 1st International Conference on TOEFL/ICOTEFL. Muhamadiyah University. Purwokerto.

Marzano, R., \& Kendall, J. (2007). The New Taxonomy of Educational Objectives $(2 n d E d)$. Thousand Oaks, CA: Corwiin Press.

Appendix A

A guide for the levels of questions based on the Cognitive Domain in Bloom's Taxonomy 


\begin{tabular}{|c|c|c|}
\hline No & Cognitive Dimension & Definitions and Instructional Verbs \\
\hline 1 & Remember & $\begin{array}{l}\text { Retrieving relevant knowledge from } \\
\text { long-term memory. } \\
\text { Question cues : } \\
\text { Memorize, Choose, Relate, Recite, Show, } \\
\text { Review, Give, Record, Example, Match, } \\
\text { Reproduce, Underline, Repeat, Cite, Listen, } \\
\text { Group, Read, Write, Outline }\end{array}$ \\
\hline 2 & Understand & $\begin{array}{l}\text { Determining the meaning of instructional } \\
\text { messages, including oral, written, and graphic } \\
\text { communication. } \\
\text { Question cues : } \\
\text { Restate, reorganize,describe, identify, report, } \\
\text { discuss, retell, research, translate, associate, } \\
\text { summaries, report, recognize, review, observe, } \\
\text { interpret }\end{array}$ \\
\hline 3 & Apply & $\begin{array}{l}\text { Carrying out or using a procedure in a given } \\
\text { situation. } \\
\text { Question cues: } \\
\text { Make, practice, apply, operate, interview, } \\
\text { discover, change, sequence, show, solve, } \\
\text { collect, demonstrate }\end{array}$ \\
\hline 4 & Analyze & $\begin{array}{l}\text { Breaking material into its constituent parts } \\
\text { and detecting how the parts relate to one another } \\
\text { and to an overall structure or purpose. } \\
\text { Question cues : } \\
\text { Distinguish, question, separate, inquire, arrange, } \\
\text { compare, contrast, survey, detect, test, debate, } \\
\text { group, investigate, research, calculate, criticize, } \\
\text { discriminate, order, sequence, analyze, diagram, } \\
\text { categorize }\end{array}$ \\
\hline 5 & Evaluate & $\begin{array}{l}\text { Making judgments based on criteria and } \\
\text { standards. } \\
\text { Question cues : } \\
\begin{array}{l}\text { Judge, rate, predict, assess, score, revise, infer, } \\
\text { determine, tell why, } \\
\text { compare,evaluate,measure,conclude,justify, } \\
\text { discriminate, appraise, probe, argue, decide, } \\
\text { criticize }\end{array}\end{array}$ \\
\hline 6 & Create & $\begin{array}{l}\text { Putting elements together to form a novel, } \\
\text { coherent whole or make an original product. } \\
\text { Question cues : } \\
\text { Compose, imagine, organize, generate, compile, } \\
\text { predict, improve,devise, invent, design, }\end{array}$ \\
\hline
\end{tabular}

JELLT (Journal of English Language and Literature Teaching)

Vol. 5 No. 02 November 2020

P.ISSN: 2548-7728 E.ISSN: 2599-0373 


\begin{tabular}{|l|l|l|}
\hline & $\begin{array}{l}\text { produce, plan, } \\
\text { prepare,develop,formulate }\end{array}$ \\
\end{tabular}

JELLT (Journal of English Language and Literature Teaching) Vol. 5 No. 02 November 2020

P.ISSN: 2548-7728 E.ISSN: 2599-0373 


\begin{tabular}{|c|c|c|c|}
\hline No & SAMPLE OF QUESTION & LEVEL & PAGE \\
\hline & UNIT 2 & & \\
\hline 1 & How do you feel when you see someone else's success? & & 13 \\
\hline 2 & $\begin{array}{l}\text { What do you say to show your feeling about someone } \\
\text { else"s success? }\end{array}$ & & 13 \\
\hline 3 & How do you feel when someone compliments you? & & 13 \\
\hline \multirow[t]{2}{*}{4} & What do you say to respond to the compliment? & & 13 \\
\hline & UNIT 6 & & \\
\hline 5 & whose birthday is it? & & 57 \\
\hline 6 & How old is she? & & 57 \\
\hline 7 & where is she having the party? & & 57 \\
\hline 8 & When we unvite someone to do something ? & & 61 \\
\hline 9 & $\begin{array}{l}\text { When we respond to someone's invitations to do } \\
\text { something? }\end{array}$ & & 61 \\
\hline 10 & When we ask for permission? & & 61 \\
\hline 11 & When we give permission? & & 61 \\
\hline \multirow[t]{2}{*}{12} & When we don't give permission? & & 61 \\
\hline & UNIT 7 & & \\
\hline 13 & Which ones are formal invitations? & & 66 \\
\hline 14 & Which one are informal invitations? & & 66 \\
\hline 15 & Who sent the card? & & 71 \\
\hline 16 & What happened to Retno? & & 71 \\
\hline 17 & Why do the senders send the cards? & & 71 \\
\hline 18 & Who is Diana? & & 71 \\
\hline 19 & Why does Anisah write the card? & & 71 \\
\hline
\end{tabular}

JELLT (Journal of English Language and Literature Teaching)

Vol. 5 No. 02 November 2020

P.ISSN: 2548-7728 E.ISSN: 2599-0373 


\begin{tabular}{|c|c|c|}
\hline 20 & Why does Mrs. Resito write the card ? & 72 \\
\hline 21 & How was the synopsis written by Salma? & 72 \\
\hline 22 & $\begin{array}{l}\text { When do people send a housewarming card like the } \\
\text { previous one? }\end{array}$ & 72 \\
\hline 23 & What does a housewarming card usually contain? & 72 \\
\hline 24 & Who is being invited & 72 \\
\hline 25 & Why is there a party? & 72 \\
\hline 26 & When is the party? & 72 \\
\hline 27 & Where will the party be held? & 72 \\
\hline 28 & Who is the host? & 72 \\
\hline \multirow[t]{2}{*}{29} & How can the receiver of the invitations reply? & 72 \\
\hline & UNIT 11 & \\
\hline 30 & Who visited Wrangell-St.Elias? & 139 \\
\hline 31 & What is Wrangell-St.Elias? & 139 \\
\hline 32 & Where is it located? & 139 \\
\hline \multirow[t]{2}{*}{33} & $\begin{array}{l}\text { How big is it, compared to the country of Switzerland and } \\
\text { the Yellowstone Park? }\end{array}$ & 139 \\
\hline & UNIT 12 & \\
\hline 34 & When do we use simple past? & 159 \\
\hline 35 & What do you know about regular verbs? & 159 \\
\hline 36 & What do you know about irregular verbs? & 159 \\
\hline 37 & What is your strategy to memorize irregular verbs? & 159 \\
\hline 38 & When do we use past continuous tense? & 159 \\
\hline \multirow[t]{2}{*}{39} & $\begin{array}{l}\text { What are the differences between simple past and past } \\
\text { continuous tense? }\end{array}$ & 159 \\
\hline & UNIT 13 & \\
\hline 40 & What is the purpose of a recount text? & 167 \\
\hline 41 & What tense is usually use in recount text ? & 167 \\
\hline
\end{tabular}

JELLT (Journal of English Language and Literature Teaching)

Vol. 5 No. 02 November 2020

P.ISSN: 2548-7728 E.ISSN: 2599-0373 


\begin{tabular}{|c|c|c|}
\hline 42 & What was Eric doing that morning? & 170 \\
\hline 43 & What did he find? & 170 \\
\hline 44 & Why did he step back into the shed? & 170 \\
\hline 45 & $\begin{array}{l}\text { What was the lizard doing when Eric saw it for the second } \\
\text { time? }\end{array}$ & 170 \\
\hline 46 & What happened at the end? & 170 \\
\hline 47 & Who were the participants in the picnic ? & 175 \\
\hline 48 & When did it take place? & 175 \\
\hline \multirow[t]{2}{*}{49} & Where did it take place? & 175 \\
\hline & UNIT 14 & \\
\hline 50 & Who is the sender of the first short message? & 182 \\
\hline 51 & Why does Tina want Iva to call her soon? & 182 \\
\hline 52 & Who is the second short message sent to ? & 182 \\
\hline 53 & Why does Tim want to borrow the book from Mike? & 182 \\
\hline 54 & What is the meaning of 'a.s.a.p' in third short message? & 182 \\
\hline 55 & Why does Mike want Bob to return his shoes? & 182 \\
\hline 56 & When do you write a short message? & 183 \\
\hline 57 & How do you write the short message? & 183 \\
\hline 58 & What media do you use to write the short message? & 183 \\
\hline \multirow[t]{2}{*}{59} & What information can you find there? & 183 \\
\hline & UNIT 15 & \\
\hline 60 & How could your school make the board more interesting? & 192 \\
\hline 61 & What does your school usually announcements? & 192 \\
\hline 62 & Who usually makes the spoken announcement? & 192 \\
\hline 63 & $\begin{array}{l}\text { What do you think we should do to make a spoken } \\
\text { announcement clear? }\end{array}$ & 192 \\
\hline
\end{tabular}

JELLT (Journal of English Language and Literature Teaching)

Vol. 5 No. 02 November 2020

P.ISSN: 2548-7728 E.ISSN: 2599-0373 


\begin{tabular}{|l|l|c|c|}
\hline 64 & $\begin{array}{l}\text { What announcement/notices do you usually see on the } \\
\text { bus ? }\end{array}$ & & 192 \\
\hline 65 & UNIT 16 & & 192 \\
\hline 66 & Wow many of the rules are related to safety? & & 200 \\
\hline 67 & How did you feel after singing the song ? & & 200 \\
\hline 68 & $\begin{array}{l}\text { What is likely the purpose of creating the song in Activity 6 } \\
?\end{array}$ & & 204 \\
\hline 69 & What is the song about ? & & 204 \\
\hline 70 & What is likely the purpose of the song ? & & 204 \\
\hline
\end{tabular}

\begin{tabular}{|c|c|c|c|}
\hline No & Question & Level & Page \\
\hline & Unit 1 & & \\
\hline 1 & Where is Claire from ? & & 12 \\
\hline 2 & What does Claire like doing on Sunday afternoon? & & 12 \\
\hline 3 & How is Claire different from her friends? & & 12 \\
\hline 4 & Why don't Hannah and Kate go near the hives? & & 12 \\
\hline \multirow[t]{2}{*}{5} & $\begin{array}{l}\text { Why does she keep the money from the honey she } \\
\text { sells? }\end{array}$ & & 12 \\
\hline & Unit 2 & & \\
\hline \multirow[t]{2}{*}{6} & Why does Mike like what he is doing ? & & 18 \\
\hline & Unit 3 & & \\
\hline 7 & What was Erin's job at the law company? & & 26 \\
\hline 8 & $\begin{array}{l}\text { Why did Erin start to look for more information about } \\
\text { Hinkley? }\end{array}$ & & 26 \\
\hline 9 & Where did the sick people in Hinkley live ? & & 26 \\
\hline 10 & What was Erin's theory about why the people were sick? & & 26 \\
\hline 11 & $\begin{array}{l}\text { How much money did Pasific Gas and Electric pay to } \\
\text { people in Hinkley? }\end{array}$ & & 26 \\
\hline 12 & What does Erin Brockovich do now? & & 26 \\
\hline 13 & $\begin{array}{l}\text { Which of the people in the text did you already know } \\
\text { about? }\end{array}$ & & 30 \\
\hline 14 & What other ways can you think of to remember heroes? & & 30 \\
\hline \multirow[t]{2}{*}{15} & How are heroes remembered in your country? & & 30 \\
\hline & Unit 4 & & \\
\hline 16 & How many sports do you know in English ? & & 32 \\
\hline 17 & what is your favorite sport? & & \\
\hline 18 & What nasionalities were the two men ? & & 32 \\
\hline 19 & $\begin{array}{l}\text { Why didn't the American and Chinese players talk to } \\
\text { each other? }\end{array}$ & & 33 \\
\hline 20 & Why did Cowan get on the Chinese team Bus? & & 33 \\
\hline
\end{tabular}

JELLT (Journal of English Language and Literature Teaching)

Vol. 5 No. 02 November 2020

P.ISSN: 2548-7728 E.ISSN: 2599-0373 


\begin{tabular}{|c|c|c|}
\hline 21 & Why didn't Cowan give Zedong a present immediately? & 33 \\
\hline 22 & $\begin{array}{l}\text { Why were there reporters at the hotel when the bus } \\
\text { arrived? }\end{array}$ & 33 \\
\hline \multirow[t]{2}{*}{23} & $\begin{array}{l}\text { Do you think that Zedong and Cowan stayed friends for a } \\
\text { long time? why/why not? }\end{array}$ & 33 \\
\hline & Unit 5 & \\
\hline 24 & In what ways are the people above different? & 40 \\
\hline 25 & in what ways are they similar? & \\
\hline 26 & In what ways is this person successful? & 40 \\
\hline 27 & $\begin{array}{l}\text { Why do you think the text has the tittle following a dream } \\
\text { ? }\end{array}$ & 43 \\
\hline 28 & $\begin{array}{l}\text { When did Hamilton's dream to be a Formula } 1 \text { driver } \\
\text { begin ? }\end{array}$ & 43 \\
\hline 29 & What did he do when he was eight? & 43 \\
\hline 30 & What did he tell Ron Dennis when he was ten ? & 43 \\
\hline 31 & Why did Ron Dennis phone Hamilton ? & 43 \\
\hline 32 & $\begin{array}{l}\text { How old was Hamilton when he joined Mc'larens } \\
\text { programme? }\end{array}$ & 43 \\
\hline 33 & $\begin{array}{l}\text { What happened when Hamilton started driving in } \\
\text { Formula } 1 \text { races? }\end{array}$ & 43 \\
\hline \multirow[t]{2}{*}{34} & What do you know about Lewis Hamilton since 2008 ? & 43 \\
\hline & Unit 6 & \\
\hline 35 & Why do the women in Okinawa live a long time ? & 46 \\
\hline 36 & Why is seaweed good for you? & 46 \\
\hline \multirow[t]{2}{*}{37} & $\begin{array}{l}\text { Where does the fat come from in the Mediterranean diet } \\
\text { ? }\end{array}$ & 46 \\
\hline & Unit 7 & \\
\hline 38 & What do you think the text is about? & 54 \\
\hline 39 & Which country has the most official languages? & 57 \\
\hline 40 & What is the most frequent letter in English ? & 57 \\
\hline 41 & $\begin{array}{l}\text { In which African country does everyone speak the same } \\
\text { language? }\end{array}$ & 57 \\
\hline \multirow[t]{2}{*}{42} & Which letter is the name of a river in the USA ? & 57 \\
\hline & Unit 9 & \\
\hline 43 & What do you think of each method? & 73 \\
\hline \multirow[t]{2}{*}{44} & What other methods of fortune telling do you know of ? & 73 \\
\hline & Unit 10 & \\
\hline 45 & $\begin{array}{l}\text { Would you like to see the film Wings of Hope ? why/why } \\
\text { not? }\end{array}$ & 75 \\
\hline \multirow[t]{2}{*}{46} & $\begin{array}{l}\text { Why do you think Werner Herzog decided to make a film } \\
\text { about the plane crash? }\end{array}$ & 75 \\
\hline & Unit 11 & \\
\hline 47 & How do you celebrate the New Year in you country? & 82 \\
\hline 48 & Where is Times Square? & 82 \\
\hline 49 & $\begin{array}{l}\text { What appears in Times Square just before midnight on } \\
31 \text { December? }\end{array}$ & 82 \\
\hline 50 & What do you hear at midnight in Times Square ? & 82 \\
\hline 51 & What happens to many new year's resolutions? & 82 \\
\hline 52 & When did reggae become popular? & 86 \\
\hline 53 & How is reggae different from rock music? & 86 \\
\hline 54 & What did Jimmy Cliff combine? & 86 \\
\hline \multirow[t]{2}{*}{55} & Who did Bob Marley play with originally & 86 \\
\hline & Unit 12 & \\
\hline
\end{tabular}

JELLT (Journal of English Language and Literature Teaching)

Vol. 5 No. 02 November 2020

P.ISSN: 2548-7728 E.ISSN: 2599-0373 


\begin{tabular}{|c|c|c|}
\hline 56 & What do you think the text is about? & 88 \\
\hline 57 & $\begin{array}{l}\text { Why did Mr Wilson fall onto the platform and then the } \\
\text { track? }\end{array}$ & 88 \\
\hline 58 & How deep was the space where Mr Wilson fell ? & 88 \\
\hline 59 & Why did five subway carriages travel over the two men? & 88 \\
\hline 60 & $\begin{array}{l}\text { Who was Mr Brown worried about when the train stopped } \\
\text { ? }\end{array}$ & 88 \\
\hline \multirow[t]{2}{*}{61} & What was the only thing that happened to Mr Brown? & 88 \\
\hline & Unit 13 & \\
\hline 62 & Who is the man in the picture ? & 100 \\
\hline 63 & What's his job? & 101 \\
\hline 64 & Where is he from? & 101 \\
\hline 65 & $\begin{array}{l}\text { Which facts about Ecuador are new to you ? which ones } \\
\text { did you alredy know? }\end{array}$ & 101 \\
\hline 66 & $\begin{array}{l}\text { What is your reaction to the story about Ulises de la Cruz } \\
\text { ? }\end{array}$ & 101 \\
\hline \multirow[t]{2}{*}{67} & Do you think what he does is 'heroic' why/why not? & 101 \\
\hline & Unit 14 & \\
\hline 68 & How many records has Furman broken? & 104 \\
\hline 69 & How far has he walked with a bottle on his head? & 104 \\
\hline 70 & $\begin{array}{l}\text { How long did it take him to break three records on the } \\
\text { same day? }\end{array}$ & 104 \\
\hline
\end{tabular}

